\title{
PENGARUH RELIGIUSITAS DAN INTERAKSI SOSIAL TERHADAP PERILAKU SEKS BEBAS SISWA KELAS XI SMK NEGERI 1 WONOASRI KABUPATEN MADIUN
}

\author{
Wayan Yudhi Anggara *) \\ wayanyudhi21@gmail.com \\ Ibnu Mahmudi **) \\ mahmudiibnu@gmail.com \\ Diana Ariswanti Triningtyas **) \\ dietyas61@yahoo.co.id
}

\begin{abstract}
ABSTRAK
Adanya pelajaran tentang agama, rutinitas dalam beribadah dan memberikan pemahaman tentang interaksi sosial yang positif bagi peserta didik akan bisa memberikan antisipasi terhadap perilaku-perilaku menyimpang khususnya seks bebas pada kalangan remaja siswa. Penelitian ini bertujuan untuk mengetahui ada atau tidaknya 1) Pengaruh Religiusitas terhadap Perilaku Seks Bebas 2) Pengaruh Interaksi Sosial terhadap Perilaku Seks Bebas 3) Pengaruh Religiusitas dan Interaksi Sosial terhadap Perilaku Seks Bebas Siswa Kelas XI SMKN 1 Wonoasri Kabupaten Madiun.

Rancangan penelitian menggunakan pendekatan kuantitatif dengan metode ex-post-facto. Populasi penelitian yaitu kelas XI SMKN 1 Wonoasri dengan jumlah 360 siswa. Pengambilan sampel dilakukan dengan menggunakan Simple Random Sampling diperoleh sebanyak 55 siswa atau 21\% dari jumlah populasi 360 siswa. Hasil Penelitian dianalisis menggunakan rumus bangun korelasi Product Moment dan analisis regresi dua prediktor, dan untuk menguji koefisien regresi secara keseluruhan menggunakan uji F dengan taraf signifikan 5\%

Dari hasil data mengenai Religiusitas dan interaksi sosial terhadap perilaku seks diperoleh $F_{\text {reg }}$ sebesar 123,92 dan dikonsultasikan dengan $F_{\text {tabel }}$ untuk 55 adalah 3.17 , sehingga $F_{\text {reg }}>F_{\text {tabel }}(123,92>3.17)$. Sehingga hipotesis diterima, artinya ada pengaruh Religiusitas dan interaksi sosial terhadap perilaku seks bebas. Hasil penelitian dapat disimpulkan: (1) ada pengaruh religiusitas terhadap perilaku seks bebas siswa kelas XI SMKN 1Wonoasri Kabupaten Madiun; (2) ada pengaruh interaksi sosial terhadap perilaku seks bebas siswa kelas XI SMKN 1 Wonoasri Kabupaten Madiun; (3) ada pengaruh religiusitas dan interaksi sosial terhadap perilaku seks bebas siswa kelas XI SMKN 1 Wonoasri Kabupaten Madiun.
\end{abstract}

Kata Kunci : Religius, Interaksi Sosial, Perilaku Seks Bebas

* Wayan Yudhi Anggara adalah Mahasiswa Program Studi Bimbingan dan Konseling Fakultas Ilmu Pendidikan IKIP PGRI MADIUN.

** Ibnu Mahmudi \& Diana Ariswanti Triningtyas adalah Dosen Program Studi Bimbingan dan Konseling Fakultas Ilmu Pendidikan IKIP PGRI MADIUN. 


\section{PENDAHULUAN}

Proses pendidikan merupakan suatu sistem yang terdiri dari input, proses dan output. Input adalah peserta didik yang akan melaksanakan aktivitas belajar, proses merupakan kegiatan dari belajar mengajar sedangkan output adalah hasil dari proses yang dilaksanakan. Dari pelaksanaan proses pendidikan tersebut diharapkan dapat menghasilkan sumber daya manusia yang berkualitas dan berdaya saing yang tinggi untuk menghadapi persaingan di era globalisasi dewasa ini.

Pada era globalisasi ini cukup banyak permasalahan yang terjadi dalam lingkup remaja di sekolah, diantaranya adalah perilaku seks bebas. Perilaku seksual merupakan suatu perbuatan perilaku individu yang mendorong individu untuk berbuat seks. Perilaku seks bebas pada dasarnya dipengaruhi oleh beberapa faktor, yaitu faktor eksternal dan faktor internal. Faktor eksternal yaitu faktor yang berasal dari dalam diri siswa, yang meliputi religiusitas individu sedangkan faktor eksternal adalah faktor yang berasal dari luar individu yang meliputi interaksi dalam lingkungan sosial.

Anshori, 1980 (dalam Ghufron \& Risnawita, 2011:168) memberikan arti agama secara detail, yakni agama sebagai suatu sistem credo (tata keyakinan atas kaidah) yang mengatur hubungan manusia dengan sesama manusia dan dengan alam sekitarnya, sesuai dengan tata keimanan dan tata peribadatan tersebut.

Semakin baik atau tinggi keimanan seseorang maka akan semakin mudah individu menghindari adanya perilaku seks bebas pada kalangan remaja di sekolah. Itu membuktikan bahwa dibutuhkan suatu religiusitas atau keyakinan terhadap agamanya dalam membangun keimanan dengan tujuan menghindari adanya perilaku yang menyimpang khususnya perilaku seks bebas pada kalangan remaja di sekolah.

Siswa yang mempunyai religiusitas rendah, pasti akan diikuti dengan munculnya godaan-godaan untuk melakukan perbuatan yang dilarang oleh agama. Oleh karena itu 
sangat dibutuhkan keimanan dan keyakinan dengan tujuan untuk membentengi diri dari godaan halhal yang dilarang oleh agama termasuk perilaku seks pada remaja dibawah umur.

Berdasarkan hasil observasi pada tanggal 15 Maret 2015, bahwa siswa SMKN 1 Wonoasri terdapat permasalahan yang berkaitan dengan kereligiusitasan dan juga menyimpang aturan agama yang berlaku di sekolah maupun masyarakat umumnya. Pendididkan agama di sekolahan sudah berjalan semestinya, tetapi siswa masa sekarang ini terutama dari kalangan remaja sangatlah rendah akan moral maupun nilai agamanya, sehingga banyak siswa yang pacaran dan melebihi batas umur berhubungan seperti layaknya orang dewasa maka bisa menjerumuskan kedalam perilaku seks bebas. Seharusnya pihak sekolah mengawasi dan membina dengan ketat perilaku siswanya agar hal-hal yang negatif salah satu nya tentang perilaku seks bebas bisa di hindari oleh siswanya.

Adapun faktor-faktor eksternal yang dapat mempengaruhi perilaku seksual pada kalangan siswa atau remaja adalah adanya interaksi sosial dengan lingkungan yang cenderung kurang positif

Menurut Wulansari (2009 : 34) interaksi sosial merupakan bentuk umum dari proses sosial dapat didefinisikan sebagai hubunganhubungan timbal balik antara individu dengan individu, kelompok dengan kelompok, serta antara individu dengan kelompok.

Interaksi sosial akan menimbulkan perilaku-perilaku yang berdampak kurang baik dalam pergaulan dan individu itu sendiri. Banyak alasan remaja kurang mampu berinteraksi dengan baik, sehingga timbul perilaku yang menyimpang misalnya perilaku seks bebas pada kalangan remaja itu sendiri yang dapat mengakibatkan adanya interaksi-interaksi yang kurang positif di sekolah. Disamping itu, masa remaja merupakan masa yang masih labil dan kurang adanya kontrol emosi sehingga timbul perilaku-perilaku yang bertentangan dengan norma-norma agama termasuk perilaku seks bebas pada kalangan remaja di sekolah. 
Religiusitas dan interaksi sosial yang cenderung positif diharapkan mampu mengendalikan dan mengarahkan remaja atau individu lebih bersikap dan berperilaku positif pula, serta mampu menjadikan individu lebih bermanfaat dan menghindari perilaku yang kurang positif.

Salah satu indikator terjadinya dan timbulnya perilaku seks adalah seorang tenaga pendidik dan peran tua yang kurang mampu memberikan informasi tentang dampak negatif yang berkaitan dengan seks di usia dini. Oleh karena itu, sangat penting peran tenaga pendidik dalam mengontrol timbulnya perilakuperilaku menyimpang khususnya tentang perilaku seks bebas.

Sarwono, 2008 (dalam Betha, 2014:138) perilaku seksual adalah segala tingkah laku yang didorong oleh hasrat seksual, baik dengan lawan jenisnya maupun dengan sesama jenis. Selain peran tenaga pendidik, perilaku seks juga dipengaruhi oleh beberapa faktor, diantaranya faktor dalam diri siswa itu sendiri atau faktor internal.
Namun pada kenyataannya, masih sering sekali ditemukan masalah-masalah yang berkaitan dengan adanya perilaku seks bebas di sekolah pada kalangan remaja, karena memang tidak cukup mudah untuk mengatasi permasalahan yang berkaitan dengan perilaku menyimpang khususnya perilaku seks tersebut. Sehingga sangat dibutuhkan kesadaran dari dalam diri dan adanya dukungan dan interaksi sosial dari lingkungan yang positif.

Penyebab tingginya perilaku seks bebas disebabkan kurangnya pendidikan dan pengetahuan siswa remaja pada ilmu agama. Pengaruh interaksi yang cenderung kurang positif yang mengarahkan remaja siswa pada pergaulan yang negatif, sehingga diperlukan adanya religiusitas dari dalam diri siswa dan interaksi yang cenderung mendorong siswa ke arah positif sehingga mengurangi terjadinya perilaku seks bebas pada kalangan remaja di sekolah.

Realitas tersebut apabila tidak segera dicari solusi permasalahannya akan menimbulkan masalah lain yang mampu menghambat 
perkembangan siswa itu sendiri. Adanya pelajaran tentang agama, rutinitas dalam beribadah dan memberikan pemahaman tentang interaksi sosial yang positif bagi peserta didik akan bisa memberikan antisipasi terhadap perilaku-perilaku menyimpang khususnya seks bebas pada kalangan remaja siswa.

\section{KAJIAN TEORI}

1. Religiusitas

a) Pengertian Religiusitas

Gazalba, 1987 (dalam

Ghufron \& Risnawita, 2011:167) reigiusitas berasal dari kata riligi dalam bahasa latin "riligio" yang berakar katanya adalah religure yang berati mengikat. Dengan demikian mengandung makna bahwa religi atau agama pada umumnya memiliki aturanaturan dan kewajibankewajiban yang harus dipatuhi dan dilaksanakan oleh pemeluknya.

Muhaimin (dalam Naim, 2012: 124) menyatakan bahwa religius memang tidak selalu identik dengan kata agama. Kata religius lebih tepat diterjemahkan sebagai keberagaman. Keberagaman lebih melihat aspek yang ada di dalam lubuk hati nurani pribadi, sikap personal yang sedikit banyak merupakan misteri orang lain, karena menapaskan intimasi, cita rasa yang mencakup totalitas ke dalam pribadi manusia, dan bukan aspek bersifat formal.

Anshori, 1980 (dalam Ghufron \& Risnawita, 2011:168) memberikan arti agama secara detail, yakni agama sebagai suatu sistem credo (tata keyakinan) atas kaidah) yang mengatur hubungan manusia dengan sesama manusia dan dengan alam sekitarnya, sesuai dengan tata keimanan dan tata peribadatan tersebut.

Dari berbagai pendapat di atas dapat ditarik kesimpulan bahwa religiusitas adalah tingkat ketaatan individu terhadap agamanya, hal ini ditunjukkan individu telah menghayati dan menginternalisasikan ajaran 


$$
\begin{aligned}
& \text { agamanya sehingga } \\
& \text { berpengaruh dalam segala } \\
& \text { tindakan dan pandangan } \\
& \text { hidupnya. }
\end{aligned}
$$

b) Dimensi-dimensi Religiusitas

Pembagian dimensidimensi religiusitas menurut Glock dan Strark (dalam Ghufron \& Risnawita, 2011:168) terdiri dari lima dimensi diantaranya :

1) Dimensi keyakinan (the ideological dimension)

Dimensi keyakinan adalah tingkatan sejauh mana seseorang menerima dan mengakui hal-hal yang dogmatik dalam agamanya. Misalnya keyakinan adanya sifatsifat Tuhan, adanya Malaikat, surga, para Nabi dan sebagainya.

2) Dimensi peribadatan atau praktik agama (the ritualistic dimension)

Dimensi ini adalah tingkatan sejauh mana seseorang menaikkan kewajiban-kewajiban ritual dalam agamanya misalnya menunaikan shalat, zakat, puasa, haji, dan sebagainya.

3) Dimensi feeling atau penghayatan the experiencal dimension)

Dimensi pengahayatan adalah perasaan keagamaan yang pernah dialami dan dirasakan seperti merasa dekat dengan Tuhan, tentram, saat berdoa, tersentuh mendengar ayat kitab suci, merasa takut berbuat dosa, merasa senang doanya terkabulkan, dan sebagainya.

4) Dimensi pengetahuan agama (the intellectual dimension)

Dimensi ini adalah seberapa jauh seseorang mengetahui dan memahami ajaran-ajaran agamanya terutama yang ada dalam kitab suci, hadist, pengetahuan tentang fikih, dan sebagainya. 
5) Dimensi effect atau pengamalan (the consequential dimension)

Dimensi pengamalan adalah sejauh mana implikasi ajaran agama memengaruhi perilaku seseorang dalam kehidupan sosial. Misalnya mendermakan harta untuk keagamaan dan sosial, menjenguk orang sakit, silahturahmi, dan sebagainya.

Glock dan Stark (dalam Ancok dan Suroso, 2004: 77) juga mengemukakan dimensidimensi dalam religiusitas, diantaranya :

1) Pertama,

Dimensi

keyakinan atau ideologis

Dimensi ini berisi pengharapan-pengharapan dimana orang religius berpegang teguh pada pandangan theologis tertentu dan mengakui kebenaran doktrin-doktrin tersebut.

2) Kedua, Dimensi praktik agama
Dimensi ini mencakup perilaku pemujaan, ketaatan, dan hal-hal yang dilakukan orang untuk menunjukkan komitmen terhadap agama yang dianutnya.

3) Ketiga, Dimensi pengalaman

Dimensi ini berisikan dan memperhatikan fakta bahwa semua agama mengandung pengharapan-pengharapan tertentu, meski tidak tepat jika dikatakan bahwa seseorang yang beragama dan baik pada suatu waktu akan mencapai pengetahuan subyektif dan langsung mengenai kenyataan terakhir (kenyataan terakhir bahwa dia akan mencapai suatu kontak dengan kekuatan super natural).

4) Keempat, Dimensi pengetahuan agama

Dimensi ini mengacu kepada harapan bahwa orang-orang yang beragama paling tidak memiliki sejumlah minimal 


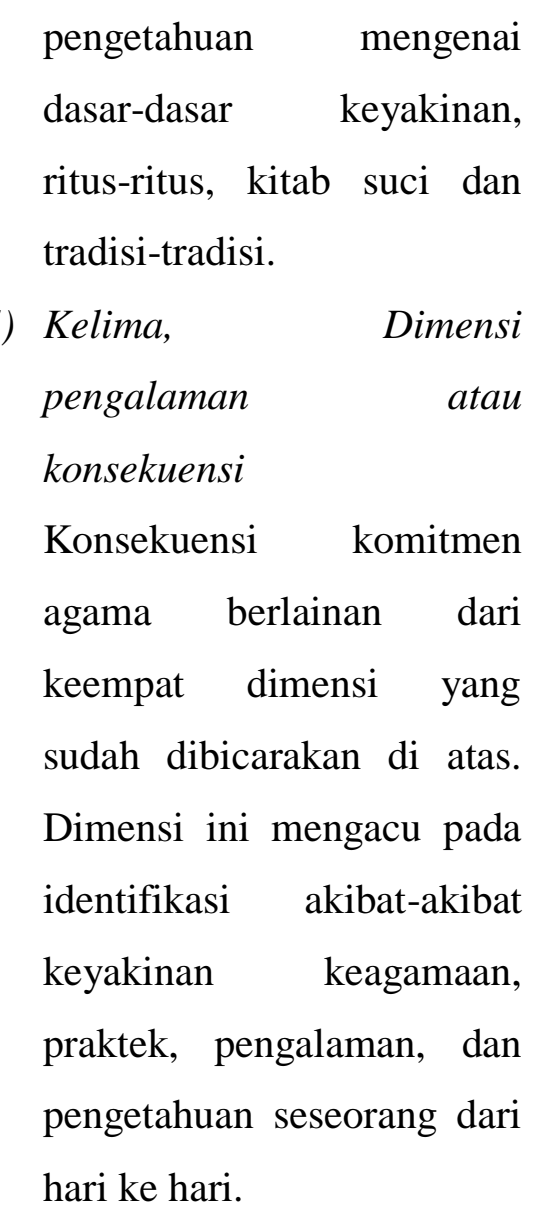

2. Interaksi Sosial

Menurut Wulansari (2009 : 34) interaksi sosial merupakan bentuk umum dari proses sosial dapat didefinisikan sebagai hubungan-hubungan timbal balik antara individu dengan individu, kelompok dengan kelompok, serta antara individu dengan kelompok.

Menurut Soekanto (2009:55) interaksi sosial merupakan dasar proses sosial, yang menunjuk pada hubungan-hubungan sosial yang dinamis.

\begin{abstract}
Berdasarkan beberapa pengertian di atas peneliti berpendapat bahwa interaksi sosial adalah peristiwa saling berkomunikasi dalam prosesproses sosial di masyarakat yang melibatkan adanya penerimaan, keterbukaan, penghargaan, dan pengertian antara individu dengan individu, individu dengan kelompok maupun kelompok dengan kelompok.
\end{abstract}

\section{Perilaku Seks Bebas}

Sunanti (2001:30) Seks adalah kebutuhan alamiah pada setiap remaja yang sehat. Bahwa, timbulnya dorongan seks (libido seksualitis) dan tanda-tanda seksual sekunder (misalnya, payudara, haid, dan mimpi basah) merupakan salah satu ciri hakiki keremajaan.

$\begin{array}{ccc}\text { Menurut May (dalam } & \text { Jess } \\ \text { dan Gregory, } & \text { 2010: } & 58 \text { ) }\end{array}$ menjelaskan bahwa seks adalah fungsi biologis yang dapat dipuaskan melalui hubungan seksual atau cara melepaskan tekanan seksual lainnya.

Menurut Sarwono, 2008 (dalam Betha, 2014:138) perilaku 
seksual adalah segala tingkah laku yang didorong oleh hasrat seksual, baik dengan lawan jenisnya maupun dengan sesama jenis.

Dari beberapa definisi para ahli di atas dapat disimpulkan bahwa perilaku seks bebas adalah suatu tingkah laku seksual yang menyimpang yang didorong oleh hasrat seksual (libido seksual) yang merupakan ciri dari masa remaja.

\section{METODOLOGI PENELITIAN}

1. Metode dan Desain Penelitian

Metode yang digunakan dalam penelitian ini menggunakan metode deskripsi korelasional ex post facto, yaitu suatu penelitian ilmiah yang penelitinya tidak secara langsung memanipulasi dan mengendalikan satu atau lebih variabel bebas serta mengamati variabel terikat untuk melihat perbedaan yang sesuai dengan manipulasi variabel-variabel itu (Arikunto 2010: 17). Penggunaan deskriptif korelasi ex post facto ini dipandang cukup representatif untuk mengetahui ada atau tidaknya pengaruh religiusitas dan interaksi sosial terhadap perilaku seks.

2. Teknik Pengumpulan Data

Teknik pengumpulan data dalam penelitian ini menggunakan teknik angket. Instrumen dalam penelitian ini disesuaikan dengan teknik pengambilan data. Adapun metode angket yang digunakan peneliti dalam penelitian ini adalah angket tertutup dalam bentuk pilihan ganda yaitu responden memilih jawaban yang disediakan dengan pilihan jawaban a (selalu), b (sering), c (kadang-kadang), d (tidak pernah). Jumlah itern untuk masing-masing variabel sama yaitu 20 item sehingga total item pertanyaan pada angket adalah 60 .

3. Analisis Data

Untuk menganalisis digunakan rumus "regresi dua predictor”. Rumus bangun "Analisis Regresi Linier : Dua-Prediktor" sebagai berikut :

Koefisien korelasi antara kriterium $\mathrm{Y}$ dengan $\mathrm{X}_{1}$ dan $\mathrm{X}_{2}$ dapat diperoleh dari rumus : 


$$
R_{y(1,2)}=\sqrt{\frac{a_{1} \sum x_{1} y+a_{2} \sum x_{2} y}{\sum y^{2}}}
$$

(Suharsimi Arikunto, 2009: 387)

Keterangan :

$$
R_{y(1,2)}: \text { Koefisien korelasi }
$$

$\operatorname{antara} \mathrm{Y}$ dengan $\mathrm{X}_{1}$ dan $\mathrm{X}_{2}$

$$
\boldsymbol{a}_{2} \text { : Koefisien prediktor }
$$

$\mathrm{X}_{2}$

$\boldsymbol{a}_{1}$ : Koefisien prediktor

$\mathrm{X}_{1}$

$\sum x_{1} y:$ Jumlah produk antara

$\mathrm{X}_{1}$ dan $\mathrm{Y}$

$\sum x_{2} y$ : Jumlah produk antara

$\mathrm{X}_{2}$ dan $\mathrm{Y}$

$\sum y^{2}$ : Jumlah kuadrat

kriterium $Y$

Untuk menguji

keberartian koefesien regresi secara keseluruhan digunakan

uji $\mathrm{F}$ dengan rumus bagan

sebagai berikut:

$$
F_{r e g}=\frac{R^{2}(N-m-1)}{m\left(1-R^{2}\right)}
$$

(Arikunto, 2009: 100 )

Keterangan:

$\mathrm{F}_{\mathrm{reg}} \quad$ : Harga $\mathrm{F}$ garis regresi

$\mathrm{N}$ : Cacah Kasus

M : Cacah Prediktor

$R \quad$ : Koefisien korelasi

antara kriterium dengan

prediktor-prediktor

\section{HASIL PENELITIAN}

1. Deskripsi Data

a. Deskripsi Data Religiusitas

Berdasarkan hasil angket yang disebarkan kepada responden mengenai

Religiusitas siswa kelas XI SMKN 1 Wonoasri Kabupaten Madiun, diperoleh hasil hitung Mean $=61,52$ Median $=63,00$, Modus $=63,00$ dan Standart Deviasi $=6,18$. Nilai Maximum $=72, \quad$ Nilai Minimum $=47$. Selanjutnya banyak kelas interval 5, diperoleh panjang kelas 6 . 
Tabel 1 . Distribusi Frekuensi Data Religiusitas

\begin{tabular}{|c|c|c|}
\hline Interval & $\mathbf{X i}$ & Frekuensi \\
\hline $72-76$ & 74 & 2 \\
\hline $67-71$ & 69 & 11 \\
\hline $62-66$ & 64 & 18 \\
\hline $57-61$ & 59 & 13 \\
\hline $52-56$ & 54 & 6 \\
\hline $47-51$ & 49 & 5 \\
\hline
\end{tabular}

Dari data distribusi frekuensi Religiusitas di atas, dapat disajikan sebagai berikut:

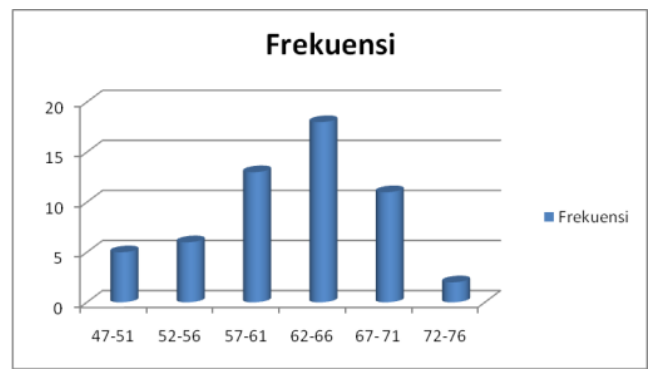

Gambar 1. Data Religiusitas

b. Deskripsi Data Interaksi Sosial

Berdasarkan hasil angket yang disebarkan kepada responden mengenai interaksi sosial siswa kelas XI SMKN 1 Wonoasri Kabupaten Madiun, diperoleh hasil hitung Mean = 62,45, Median $=63,00$, Modus $=54$, dan Standart Deviasi $=$ 6,051, Nilai Maximum $=73$, Nilai Minimum $=49$. Selanjutnya banyak kelas interval 5, dan diperoleh panjang kelas 5 .

Tabel 2. Distribusi Frekuensi Data Interaksi sosial

\begin{tabular}{|c|c|c|}
\hline Interval & Xi & Frekuensi \\
\hline $69-73$ & 71 & 8 \\
\hline $64-68$ & 66 & 18 \\
\hline $59-63$ & 61 & 16 \\
\hline $54-58$ & 56 & 8 \\
\hline $49-53$ & 51 & 5 \\
\hline
\end{tabular}

Dari data distribusi frekuensi interaksi sosial diatas, dapat disajikan sebagai berikut:

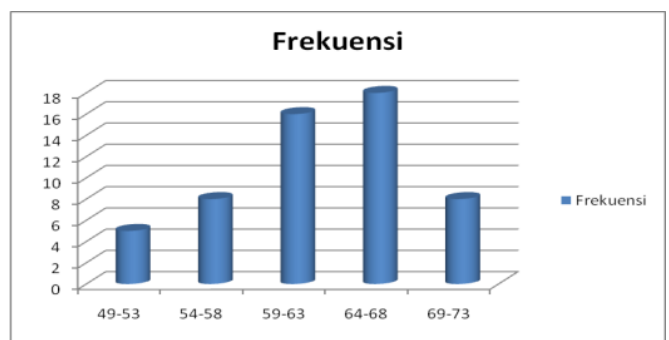

Gambar 2. Data Interaksi social 
c. Deskripsi Data Perilaku seks bebas

Berdasarkan hasil angket yang disebarkan kepada responden mengenai perilaku seks bebas siswa kelas XI SMK Negeri 1 Wonoasri Kabupaten Madiun, diperoleh hasil hitung Mean $=61,07$, Median $=63,00$, Modus $=63$, dan Standart Deviasi $=6,857$. Nilai Maximum $=74$, Nilai Minimum $=40$. Selanjutnya banyak kelas interval adalah 5, dan diperoleh panjang kelas 7 . Tabel 3. Distribusi Frekuensi Data Perilaku seks bebas

\begin{tabular}{|c|c|c|}
\hline Interval & $\mathbf{X i}$ & Frekuensi \\
\hline $70-74$ & 71 & 6 \\
\hline $65-69$ & 66 & 11 \\
\hline $60-64$ & 61 & 18 \\
\hline $55-59$ & 56 & 10 \\
\hline $50-54$ & 51 & 7 \\
\hline $45-49$ & 46 & 2 \\
\hline $40-44$ & 41 & 1 \\
\hline Jumlah & \multicolumn{2}{|c|}{55} \\
\hline \multicolumn{3}{|c|}{ Dari data distribusi }
\end{tabular}

frekuensi perilaku seks diatas, dapat disajikan sebagai bekikut:

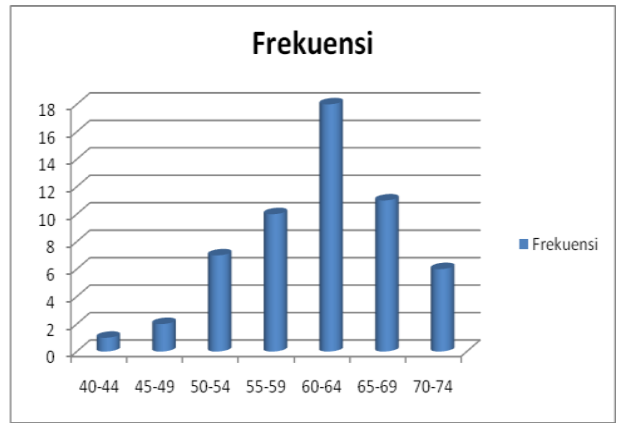

Gambar 3. Data Perilaku seks bebas

2. Hasil Pengujian Hipotesis

Analisis data dihitung dengan menggunakan rumus korelasi product moment dan regresi dua prediktor. Data hasil perhitungan sebagai berikut:

a. Religiusitas terhadap perilaku seks bebas

Hasil analisis data mengenai Religiusitas terhadap perilaku seks diperoleh $r_{\text {hitung }}$ sebesar 0,751 . Setelah dikonsultasikan dengan $\mathrm{r}_{\text {tabel }}$ untuk $\mathrm{N}=55$, dengan taraf signifikan sebesar 0,05 adalah 0,266 sehingga $r_{\text {hitung }}>r_{\text {tabel }}(0,751>$ 0,266). Sehingga hipotesis diterima artinya ada pengaruh religiusitas terhadap perilaku seks.

b. Interaksi sosial terhadap perilaku seks bebas 


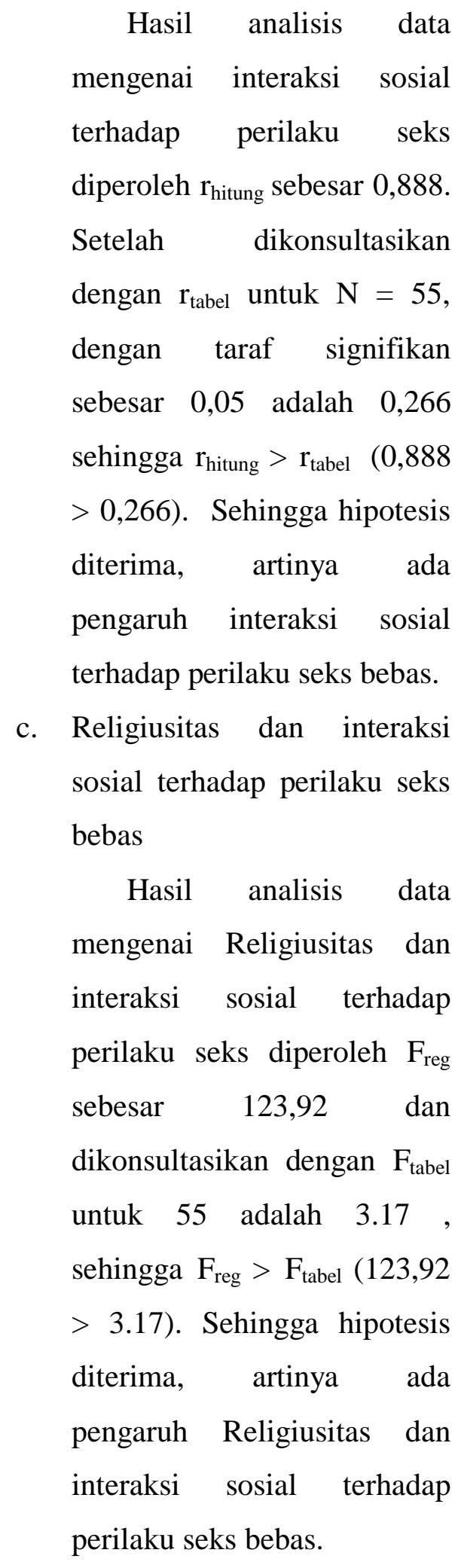

\section{SIMPULAN DAN SARAN}

1. Simpulan

Berdasarkan hasil dari penelitian maka dapat diambil simpulan sebagai berikut:
a. Ada Pengaruh Religiusitas Terhadap Perilaku Seks Bebas siswa kelas XI SMKN 1 Wonoasri Kabupaten Madiun.

b. Ada Interaksi Sosial Terhadap Perilaku Seks Bebas siswa kelas XI SMKN 1 Wonoasri Kabupaten Madiun.

c. Ada Pengaruh Secara Simultan Religiusitas dan Interaksi sosial Terhadap Perilaku Seks Bebas Siswa kelas XI SMKN 1 Wonoasri Kabupaten Madiun.

2. Saran

Berdasarkan penelitian diperoleh hasil bahwa Ada Pengaruh Secara Simultan Religiusitas Dan Interaksi sosial Terhadap Perilaku Seks Siswa Kelas XI SMKN 1 Wonoasri Kabupaten Madiun. 
Agar dapat menekan terjadinya perilaku seks bebas di kalangan siswa maka peneliti memberi saran sebagai berikut:

a) Bagi sekolah

Dalam upaya menekan perilaku seks pada siswa sekolah lebih memberikan perhatian kepada tumbuh kembang siswa dan memberikan kegiatan sekolah yang positif supaya siswa memiliki kepribadian yang positif pula.

b) Bagi Guru dan Konselor Sekolah

Guru dan konselor memantau perkembangan siswa dengan menanamkan religiusitas serta memberikan informasi-informasi dengan tujuan menekan terjadinya perilaku seks pada siswa.

c) Bagi Orang tua

Orang tua perlu lebih memberikan contoh dalam penanaman Religiusitas pada siswa agar mampu berkembang dengan kepribadian yang positif dan mampu menjauhi perilaku-perilaku negatif khususnya perilaku seks bebas pada siswa.

d) Bagi Siswa

Para siswa diharapkan mampu mengetahui dan menyadari perlunya Religiusitas dan giat melakukan interaksi guna mendapat informasiinformasi dari sekolah maupun lingkungan sosial dengan tujuan pencegahan terjadinya perilaku seks bebas.

\section{DAFTAR PUSTAKA}

Ancok, D. \& Fuat N. S. 2004.Psikologi Islami. Solusi Islam atas Problem-problem Psikologi. Jogjakarta: Pustaka Pelajar.

Betha, F \& Ahyani, F.Jurnal Psikologi. Perilaku Seksual Pranikah Ditinjau Dari Intensitas Cinta dan Sikap Terhadap Pornografi Pada Dewasa Awal. Riau: UIN SUTAN SYARIF Riau. Didownload tanggal 1 April 2015 Pukul 08.00 
Feist, J.\& Gregory, F. 2010. Teori Kepribadian. Jakarta: Salemba Humanika.

Ghufron, N \& Risnawati, R. S. 2011. Teori-Teori Psikologi. Jogjakarta: Ar-Ruzz Media.

Naim, N. 2012. Character Building. Optimalisasi Peran Pendidikan dalam Pengembangan Ilmu dan Pembentukan Karakter Bangsa. Jogjakarta: Ar- Ruzz Media.

Soekanto, S. 2009. Sosiologi Suatu Pengantar. Jakarta: Grafindo Persada.

Sugiyono. 2010. Metode Penelitian Kuantitatif Kuantitatif dan $R \& D$. Bandung: Alfabeta.
Arikunto, S. 2009. Prosedur Penelitian. Suatu Pendekatan Praktik. Jakarta: PT Renika Cipta. 2010. Prosedur Penelitian. Suatu Pendekatan Praktik. Jakarta: PT Renika Cipta.

Sunanti, Z. S. 2001. Perilaku Seks di Kalangan Remaja dan Permasalahannya. Media Litbang Kesehatan Volume XI Nomor 1 Tahun 2001. Puslitbang Ekologi Kesehatan. Diunduh tanggal 20 Maret 2015 pukul 18.29

Wulansari, D. 2009. Sosiologi (Konsep dan Teori). Bandung: Refika

Aditama. 